\title{
PENYULUHAN DEMAM BERDARAH DI PUSKESMAS PAYUNG SEKAKI
}

TAHUN 2020

\author{
Yulrina Ardhiyanti, Tika Azhari \\ STIKes HANG TUAH PEKANBARU
}

\begin{abstract}
Dengue Hemorrhagic Fever (DHF) is still one of the major public health problems in Indonesia. DHF is a disease caused by the dengue virus which is transmitted from person to person through the bite of the Aedes Aegypti mosquito. Dengue hemorrhagic fever appears as an Extraordinary Event $(K L B)$ that causes panic in the community because it risks causing death and its spread very quickly. The incidence of dengue fever continues to increase from21,092 (in 2015) to 25,336 people (in 2016). The purpose of the activity is to increase public knowledge about Dengue Hemorrhagic Fever (DHF). The method used was outreach to the community and providing leaflets containing information on Dengue Hemorrhagic Fever (DHF). Health workers should routinely provide information about Dengue Hemorrhagic Fever (DHF) so that public awareness increases the importance of implementing prevention with $3 M$ plus.
\end{abstract}

\section{Keywords : Dengue Fever, Education}

\begin{abstract}
ABSTRAK
Penyakit Demam Berdarah Dengue (DBD) masih merupakan salah satu masalah kesehatan masyarakat yang utama di Indonesia. DBD merupakan penyakit yang disebabkan oleh virus dengue yang ditularkan dari orang ke orang melalui gigitan nyamuk Aedes Aegypti. Demam berdarah dengue muncul sebagai Kejadian Luar Biasa (KLB) sehingga mengakibatkan kepanikan di masyarakat karena berisiko meyebabkan kematian serta penyebarannya sangat cepat. Angka kejadian demam berdarah terus meningkat dari 21.092 (tahun 2015) menjadi 25.336 orang (tahun 2016). Tujuan kegiatan adalah untuk meningkatkan pegetahuan masyarakat tentang peyakit Demam Berdarah Dengue (DBD). Metode yang digunakan adalah penyuluhan terhadap masyarakat dan memberikan leaflet yang berisi tentang informasi Penyakit Demam Berdarah Dengue (DBD). Kepada petugas kesehatan agar rutin memberikan informasi tentang Penyakit Demam Berdarah Dengue (DBD) sehingga kesadaran masyarakat meningkat akan pentingnya menerapkan pencegahan dengan $3 \mathrm{M}$ plus.
\end{abstract}

\section{Kata Kunci : Demam Berdarah, Penyuluhan}




\section{PENDAHULUAN}

Penyakit Demam Berdarah Dengue (DBD) masih merupakan salah satu masalah kesehatan masyarakat yang utama di Indonesia. DBD merupakan penyakit yang disebabkan oleh virus dengue yang ditularkan dari orang ke orang melalui gigitan nyamuk Aedes aegypti. Aedes aegypti merupakan vektor yang paling utama, namun spesies lain seperti A. albopictus juga dapat menjadi vektor penular. Selain kedua spesies ini masih ada beberapa spesies dari nyamuk Aedes yang bisa bertindak sebagai vektor untuk virus dengue seperti A. rotumae, A.cooki dan lain-lain (WHO, 2014).

Salah satu penyakit menular yang masih menjadi masalah kesehatan masyarakat di Indonesia adalah Demam Berdarah Dengue (DBD). Demam berdarah dengue muncul sebagai Kejadian Luar Biasa (KLB) sehingga mengakibatkan kepanikan di masyarakat karena berisiko meyebabkan kematian serta penyebarannya sangat cepat. Angka kejadian demam berdarah terus meningkat dari 21.092 (tahun 2015) menjadi 25.336 orang (tahun 2016) (Dinkesprov Jawa Tengah, 2013).

Demam Berdarah Dengue masih menjadi permasalahan kesehatan baik di wilayah perkotaan maupun wilayah semiperkotaan. Perilaku vektor dan hubungannya dengan lingkungan, seperti iklim, pengendalian vektor, urbanisasi, dan lain sebagainya mempengaruhi terjadinya wabah demam berdarah di daerah perkotaan. Belum ada prediksi yang tepat untuk menunjukkan kehadiran dan kepadatan vektor (terutama Aedes Aegypti di lingkungan perkotaan dan semi perkotaan). Penyebaran dengue dipengaruhi faktor iklim seperti curah hujan, suhu dan kelembaban. Kelangsungan hidup nyamuk akan lebih lama bila tingkat kelembaban tinggi, seperti selama musim hujan (Widyaningsih, 2014).

Kelembaban yang tinggi dengan suhu berkisar antara 28-320C membantu nyamuk Aedes bertahan hidup untuk jangka waktu yang lama. Pola penyakit di Indonesia sangat berbeda antara satu wilayah dengan wilayah lainnya. Tingginya angka kejadian DBD juga dapat dipengaruhi oleh kepadatan penduduk. Peningkatan jumlah kasus DBD dapat terjadi bila kepadatan penduduk meningkat. Semakin banyak manusia maka peluang tergigit oleh nyamuk Aedes aegypti juga akan lebih tinggi (Farahiyah, 2013).

Penyakit DBD telah menjadi penyakit yang mematikan sejak tahun 2013. Penyakit ini telah tersebar di 436 kabupaten/kota pada 33 provinsi di Indonesia. Jumlah kematian akibat DBD tahun 2015 sebanyak 1.071 orang dengan 
total penderita yang dilaporkan sebanyak 129.650 orang. Nilai Incidens Rate (IR) di Indonesia tahun 2015 sebesar 50,75\% dan Case Fatality Rate (CFR) 0,83\%. Jumlah kasus tercatat tahun 2014 sebanyak 100.347 orang dengan IR sebesar 39,80\% dan CFR sebesar 0,90\% (Kemenkes RI, 2011).

\section{PERUMUSAN MASALAH}

Kurangnya pemahaman masyarakat tentang pencegahan Penyakit Demam Berdarah Dengue (DBD) dan cara penanggulangannya serta kurangnya kesadaran masyarakat untuk menjaga lingkungan dan berpartisipasi dalam pemberantasan sarang nyamuk dengan metode 3M Plus.

\section{Tujuan Kegiatan}

Tujuan kegiatan adalah untuk meningkatkan pemahaman masyarakat tentang penyakit DBD dan cara penanggulangannya, serta meningkatkan kesadaran masyarakat untuk menjaga lingkungan dan berpartisipasi dalam pemberantasan sarang nyamuk dengan metode 3M Plus sehingga dapat mencegah terjadinya penyakit DBD di wilayah kerja Puskesmas Payung Sekaki.

\section{METODE KEGIATAN}

Metode yang digunakan adalah penyuluhan terhadap masyarakat di wilayah kerja Puskesmas Payung Sekaki.

\section{HASIL}

Kegiatan penyuluhan yang dilakukan di Puskesmas Payung Sekaki pada tanggal 15 Januari 2020, langkah pertama yang dilakukan dengan pembagian leflat yang berisi tentang informasi Penyakit Demam Berdarah Dengue (DBD). Kemudian dilakukan pemberian materi tentang Demam Berdarah.

Kegiatan yang dilakukan kepada masyarakat di wilayah kerja Puskesmas Payung Sekaki memberikan hasil sebagai berikut :

1. Masyarakat antusias mendengarkan materi yang disampaikan oleh pemateri.

2. Masyarakat memahami materi yang disampaikan oleh pemateri yang dinilai melalui pertanyaan yang diajukan oleh pemateri bisa dijawab oleh responden.

\section{PEMBAHASAN}

Sebagian besar masyarakat yang berada di wilayah kerja Puskesmas Payung Sekaki kurang memahami tentang pencegahan Penyakit Demam Berdarah 
Dengue (DBD) dan cara penaggulangannya serta kurangnya kesadaran masyarakat untuk menjaga lingkungan dan berpartisipasi dalam pemberantasan sarang nyamuk dengan metode $3 \mathrm{M}$ Plus.

Setelah dilakukannya penyuluhan tentang Penyakit Demam Berdarah Dengue (DBD), pengetahuan masyarakat di wilayah kerja Puskesmas Payung Sekaki semakin meningkat.

\section{KESIMPULAN}

Pengetahuan masyarakat di wilayah kerja Puskesmas Payung Sekaki semakin meningkat tentang pencegahan Penyakit Demam Berdarah Dengue (DBD) dan cara penaggulangannya.

\section{SARAN}

Diharapkan kepada petugas kesehatan agar rutin mensosialisasikan tentang Penyakit Demam Berdarah Dengue (DBD) dan cara penanggulangannya serta megajak masyarakat untuk ikut berpartisipasi dalam pemberantasan sarang nyamuk dengan metode 3M Plus sehingga dapat mencegah terjadinya penyakit DBD di wilayah kerja Puskesmas Payung Sekaki.

\section{DAFTAR PUSTAKA}

Adi, A. A. (2015). Hubungan Lingkungan Fisik dan Tindakan PSN dengan Penyakit Demam Berdarah Dengue di Wilayah Buffer Kantor Kesehatan Pelabuhan Kelas II Samarinda. Jurnal Ilmiah Manuntung, 1(1), 19-24.

Anggraini, A. (2016). Pengaruh Kondisi Sanitasi Lingkungan dan Perilaku 3M Plus terhadap Kejadian Demam Berdarah Dengue di Kecamatan Purwoharjo Kabupaten Banyuwangi. Jurnal Pendidikan Geografi, 3(3), 321328.

Dinas Kesehatan Provinsi Jawa Tengah. (2013). Data Demam Berdarah Dengue.

Farahiyah, Musyarifatun. (2013). Analisis

Spasial Faktor Lingkungan dan Kejadian DBD di Kabupaten Demak. Magister Kesehatan Lingkungan Universitas Diponegoro.jurnal.Vol 42, no 1.

Kemenkes RI. (2011). Modul Pengendalian demam Berdarah Dengue.Ditjen PP dan PL.

Widyaningsih, Eni. (2014). Keberadaan Larva Aedes Aegypti di Lingkungan Rumah pada Berbagai Ketinggian Tempat. Skripsi.

World Health Organization. (2014). Pencegahan dan Pengendalian Demam Berdarah Dengue. ECG : Jakarta. 